\title{
Physical exercise and activity may be important in reducing dementia risk at any age
}

James A. Mortimer, PhD, and Yaakov Stern, PhD

Neurology ${ }^{\circledR}$ 2019;92:362-363. doi:10.1212/WNL.0000000000006935

Lifestyle interventions such as physical exercise may provide inexpensive and effective ways to delay the onset of cognitive decline and dementia. If we are able to reduce Alzheimer neuropathology in the future as now appears possible, ${ }^{1}$ combining pharmacologic and lifestyle interventions will likely provide the best prevention for cognitive decline and dementia. In this respect, prevention of dementia and cognitive impairment would be similar to current preventive treatments for diabetes and vascular disease, where both types of interventions are used.

Numerous observational studies have provided support for an association between physical exercise and reduction in cognitive decline and dementia. ${ }^{2}$ The mechanisms underlying this association remain unclear. The results of randomized trials of physical exercise ${ }^{3,4}$ suggest that exercise leads to increases in brain tissue, including in the hippocampus, where atrophy is an early and important finding in Alzheimer disease $(\mathrm{AD})$. One of these trials showed that aerobic exercise resulted in increased levels of brain-derived neurotrophic factor (BDNF) in association with increased hippocampal volume. ${ }^{3}$ Other studies suggest that higher BDNF gene expression may have a role in slowing cognitive decline. ${ }^{5}$ Alternatively, physical exercise itself might reduce brain pathology. Studies in animal models of $\mathrm{AD}$ have shown that higher levels of physical activity reduce the accumulation of Alzheimer pathology. ${ }^{6}$ In a recent human study, Alzheimer biomarkers were reduced in dominant $\mathrm{AD}$ mutation carriers with high vs low physical exercise. ${ }^{7}$ Another recent study suggested that even moderate exercise might be beneficial in reducing Alzheimer pathology. ${ }^{8}$

Given the current interest in sharpening terminology, ${ }^{9}$ it is important to consider the mechanisms that potentially underlie the beneficial effect of physical activity. Clearly, physical activity could increase brain maintenance: the effect of genetics or lifestyle on reduced development of age-related brain changes and pathology. The observations reviewed above regarding the improvement of brain volume by physical activity, as well as the upregulation of important neurotrophic factors, are consistent with this idea. In addition, exercise might also contribute to cognitive reserve: the adaptability (i.e., efficiency, capacity, flexibility) of cognitive processes that helps to explain differential susceptibility of cognitive abilities or day-to-day function to brain aging, pathology, or insult. For this to be the case, evidence that physical activity influences functional processes over and above the brain substrate is useful. For example, aerobic exercise has been associated with greater connectivity of the default mode network ${ }^{10}$ as well as allocation of brain resources. ${ }^{11}$ Thus, physical activity can both promote brain maintenance and cognitive reserve.

In the current issue of Neurology ${ }^{\circledR}$, Buchman et al. ${ }^{12}$ provide evidence for beneficial effects of total daily physical activity on cognitive performance that is independent of a variety of brain lesions including $\mathrm{AD}$ pathology. Building on a large longitudinal study with autopsy follow-up, they examined the association between total daily physical activity derived from wrist accelerometer recordings an average of 2 years prior to death and cognition. After adjusting for the severity of a variety of brain lesions, including quantitative measures of $\mathrm{AD}$ pathology, individuals with higher levels of total daily physical activity continued to have significantly better cognitive function. The authors attributed this finding to increased cognitive reserve associated with better physical and motor function.

\author{
Correspondence \\ Dr. Mortimer \\ jmortime@health.usf.edu
}

\section{RELATED ARTICLE}

Physical activity, common brain pathologies, and cognition in communitydwelling older adults

Page 370 
Because the data from this study are cross-sectional, causal inferences cannot be drawn. An alternative explanation for the results is that at least some of the association resulted from reverse causality, i.e., that lower cognitive function led to less physical activity. Some support for this view is provided by a large reduction in the strength of the association between physical activity and cognition when participants with dementia were excluded from the model, suggesting that as individuals become demented they may reduce their physical activity. Consistent with this view, unadjusted comparisons of physical activity in those who had dementia vs those who did not showed a significant reduction in physical activity among the participants with dementia. It is important to emphasize that this does not imply that physical activity does not increase reserve against cognitive decline, only that the effect may be more modest among those with better cognition. What is needed to establish causation are longitudinal studies of physical activity and cognition with brain imaging to document the influence of pathology on this association.

Studies that have documented benefits of physical exercise on cognition have generally focused on strenuous or aerobic exercise in earlier life. It is unclear how the effects of physical activity as measured by a wrist-worn accelerometer in late life are related to those of aerobic or other types of exercise throughout the life course. One of the only studies that examined physical activity over the life course reported low to moderate correlations between childhood, age 30 , age 50, and late-life exercise. ${ }^{13}$

Although important questions remain, currently available data suggest that promotion of an active lifestyle in late as well as early life that includes regular physical activity and exercise may be beneficial in reducing the risk of dementia, both through increases in reserve and reduction of Alzheimer neuropathology. The fact that physical exercise and activity have few if any downsides makes them an attractive target for the prevention of cognitive impairment and dementia.

\section{Study funding}

No targeted funding reported.

\section{Disclosure}

The authors report no disclosures. Go to Neurology.org/N for full disclosures.

\section{References}

1. ALZFORUM News. 2018. Four immunotherapies now banish amyloid from the brain. Available at: alzforum.org/news/conference-coverage/four-immunotherapiesnow-banish-amyloid-brain. Accessed January 9, 2019.

2. Beydoun MA, Beydoun HA, Gamaldo AA, et al. Epidemiologic studies of modifiable factors associated with cognition and dementia: systematic review and meta-analysis. BMC Public Health 2014;14:643.

3. Erickson KI, Voss MW, Prakash RS, et al. Exercise training increases size of hippocampus and improves memory. Proc Natl Acad Sci USA 2011;108:3017-3022.

4. Mortimer JA, Ding D, Borenstein AR, et al. Changes in brain volume and cognition in a randomized trial of exercise and social interaction in a community-based sample of Chinese elders. J Alzheimer Dis 2012;30:757-766.

5. Buchman AS, Yu L, Boyle PA, et al. Higher brain BDNF gene expression is associated with slower cognitive decline in older adults. Neurology 2016;86:735-741.

6. Tapia-Rojas C, Arangulz F, Varela-Naller L, Inestrosa NC. Voluntary running attenuates memory loss, decreases neuropathological changes and induces neurogenesis in a mouse model of Alzheimer's disease. Brain Pathol 2016;26:62-74.

7. Müller S, Preische O, Sohrabi HR, et al. Relationship between physical activity, cognition, and Alzheimer pathology in autosomal dominant Alzheimer's disease. Alzheimer Dement 2018;14:1427-1437.

8. Law LL, Rol RN, Schultz SA, et al. Moderate intensity physical activity associates with CSF biomarkers in a cohort at risk for Alzheimer's disease. Alzheimers Dement 2018; 10:188-195.

9. Stern Y, Arenaza-Urquijo EM, Bartrés-Faz D, et al. Whitepaper: defining and investigating cognitive reserve, brain reserve and brain maintenance. Alzheimers Dement Epub 2018 Sep 14

10. Voss MW, Prakash RS, Erickson KI, et al. Plasticity of brain networks in a randomized intervention trial of exercise training in older adults. Front Aging Neurosci 2010;2:32.

11. Prakash RS, Snook EM, Erickson KI, et al. Cardiorespiratory fitness: a predictor of cortical plasticity in multiple sclerosis. Neuroimage 2007;34:1238-1244.

12. Buchman AS, Yu L, Wilson RS, et al. Physical activity, common brain pathologies, and cognition in community-dwelling older adults. Neurology 2019;92:e811-e822.

13. Middleton LE, Barnes DE, Lui LY, Yaffe K. Physical activity over the life course and its association with cognitive performance and impairment in old age. J Am Geriatr Soc 2010;58:1322-1326. 


\section{Neurology}

\section{Physical exercise and activity may be important in reducing dementia risk at any age James A. Mortimer and Yaakov Stern}

Neurology 2019;92;362-363 Published Online before print January 16, 2019

DOI 10.1212/WNL.0000000000006935

This information is current as of January 16, 2019

$\begin{array}{ll}\begin{array}{l}\text { Updated Information \& } \\ \text { Services }\end{array} & \begin{array}{l}\text { including high resolution figures, can be found at: } \\ \text { http://n.neurology.org/content/92/8/362.full }\end{array} \\ \text { References } & \text { This article cites } 11 \text { articles, } 2 \text { of which you can access for free at: } \\ & \text { http://n.neurology.org/content/92/8/362.full\#ref-list-1 } \\ \text { Subspecialty Collections } & \text { This article, along with others on similar topics, appears in the } \\ & \text { following collection(s): } \\ & \text { All Cognitive Disorders/Dementia } \\ \text { http://n.neurology.org/cgi/collection/all_cognitive_disorders_dementia } & \\ \text { Plasticity } & \text { http://n.neurology.org/cgi/collection/plasticity } \\ \text { Risk factors in epidemiology } & \\ \text { http://n.neurology.org/cgi/collection/risk_factors_in_epidemiology } & \\ & \text { Information about reproducing this article in parts (figures,tables) or in } \\ & \text { its entirety can be found online at: } \\ & \text { http://www.neurology.org/about/about_the_journal\#permissions } \\ \text { Permissions \& Licensing } & \text { Information about ordering reprints can be found online: } \\ & \text { http://n.neurology.org/subscribers/advertise }\end{array}$

Neurology ${ }^{\circledR}$ is the official journal of the American Academy of Neurology. Published continuously since 1951, it is now a weekly with 48 issues per year. Copyright (C 2019 American Academy of Neurology. All rights reserved. Print ISSN: 0028-3878. Online ISSN: 1526-632X.

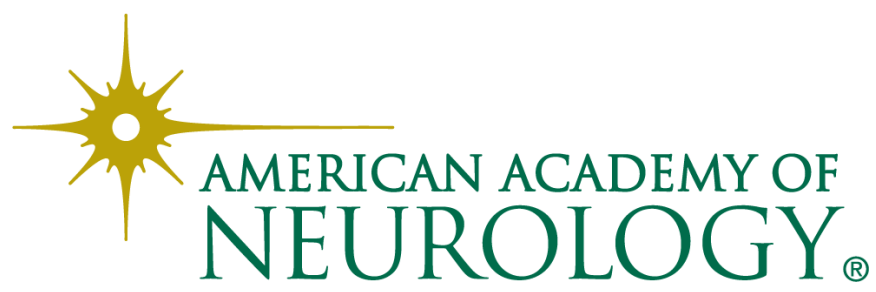

